\title{
PERSEPSI GURU PENDIDIKAN AGAMA ISLAM TERHADAP KEPEMIMPINAN PENGAWAS MADRASAH
}

\author{
Hindun ${ }^{1}$, Fathoni ${ }^{2}$ \\ ${ }^{1}$ Badan Litbang dan Diklat Kementerian Agama, ${ }^{2}$ Kantor Kementerian Agama Jakarta Utara \\ 1'hindunanwar31@gmail.com, 22zahra.alfia@gmail.com
}

https://doi.org/10.36052/ andragogi.v8i1.111

Diterima: 30 Maret 2020 | Disetujui: 29 Juni 2020 | Dipublikasikan: Juni 2020

\begin{abstract}
Abstrak
Tujuan penulisan penelitian ini untuk mendeskripsikan persepsi guru Pendidikan Agama Islam (PAI) terhadap kepemimpinan pengawas madrasah. Metode penelitian ini adalah Mixed Method yang mengkombinasikan metode kuantitatif yang didukung angket untuk menjaring data dan metode kualitatif yang didukung wawancara terhadap $20 \%$ dari populasi responden. Responden penelitian ini adalah guru PAI pada MTs Negeri dan MTs Swasta di Wilayah Jakarta Utara berjumlah 32 orang. Hasil analisis persepsi guru PAI terhadap sikap kepemimpinan pegawas di wilayah Jakarta Utara tersebut diperoleh nilai rata-rata 79,916 dengan predikat baik. Hasil wawancara adalah persepsi guru PAI terhadap kepemimpinan pengawas madrasah positif atau berkategori baik. Dengan demikian, penelitian ini menyimpulkan bahwa persepsi guru PAI terhadap sikap kepemimpinan pengawas kategori baik.
\end{abstract}

Kata Kunci: Persepsi, Kepemimpinan, Pengawas Madrasah.

\begin{abstract}
[THE PERCEPTION OF PAI TEACHER'S TO THE MADRASAH SUPERVISOR'S LEADERSHIP]. The purpose of writing this paper is to describe the PAI teacher's perception of the Madrasah Supervisor's Leadership. The research methodology of this paper is Mixed Method by combining quantitative methods supported by questionnaires to capture data and qualitative methods with the support of interviews of $20 \%$ of the respondent's population. The respondents of this study were PAl teachers at MTs Negeri and MTs Private in the North Jakarta Region totaling 32 people. The results of the analysis of the perception of PAI MTs teachers towards the attitude of the leadership of staff in the North Jakarta area obtained an average value $=79,916$, with a good predicate. Thus, the conclusions of PAl teachers 'perceptions of supervisors' leadership attitudes are in a good category.
\end{abstract}

Keywords: Perception, Leadership, Madrasah Supervisor. 


\section{PENDAHULUAN}

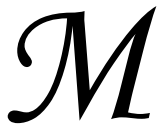
enurut Peraturan Menteri Agama Nomor 2 tahun 2012 tentang Pengawas madrasah dan Pengawas Pendidikan Agama Islam (PAI), Baba I Pasal 1 ayat (3) Pengawas Madrasah adalah guru pegawai negeri sipil yang diangkat dalam jabatan fungsional pengawas satuan pendidikan yang tugas, tanggung jawab, dan wewenangnya melakukan pengawasan akademik dan manajerial pada madrasah. Sedangkan pada Bab II Tugas dan Fungsi pasal 2 ayat (1) pengawas madrasah meliputi tugas RA, MI, MTs., MA dan/atau MAK.

Dengan demikian, pengawas madrasah melakukan supervisi akademik seperti memberi bimbingan penyusunan perangkat pembelajaran, melakukan observasi kegiatan pembelajaran guru di kelas, pembimbingan penyusunan instrumen penilaian hasil belajar siswa, pembinaan terhadap pembelajaran nilai-nilai karakter kepada PAI yang nantinya mereka meneruskan kepada peserta didik tentang akhlakul karimah tersebut. Sedangkan melakukan supervisi manajerial seperti memberi bimbingan kepada kepala madrasah dalam merumuskan visi dan misi, penyusunan program kerja madrasah, dan sebagainya.

Dalam membina dan membimbing guru serta kepala madrasah tugas pengawas madrasah tidak bisa dikatakan mudah; diperlukan kemampuan intelektual (melakukan supervisi akademik dan supervisi manajerial) dan skill kepemimpinan baik yang dapat disegani guru dan kepala madrasah. Sementara guru PAI di era digital saat ini pun tidak mudah, selain harus memiliki kompetensi ilmu agama yang diampunya, mereka pun punya tanggung jawab atau amanah dunia dan akhirat. Mengapa? Guru PAl menunaikan tugas mengajar di depan kelas sebanyak 24 jam pelajaran (JP) seminggu, merupakan tugas dinas yang harus dipenuhinya. Guru memberikan pembelajaran ibadah dan baca tulis Alquran yang nantinya akan diamalkan oleh peserta didik hingga akhir hayatnya. Tugas guru PAl membina karakter dan akhlakul karimah generasi penerus bangsa itulah perlu pembinaan, bimbingan dan dukungan pembelajaran dari pengawas madrasah.
Lebih jelas tentang tugas pengawas seperti termaktub dalam Peraturan Menteri Pendayagunaan Aparatur Negara dan Reformasi Birokrasi Nomor 21 Tahun 2010 Tentang Jabatan Fungsional Pengawas Sekolah dan Angka Kreditnya pasal 5 yaitu: Tugas pokok Pengawas Sekolah adalah melaksanakan tugas pengawasan akademik dan manajerial pada satuan pendidikan yang meliputi penyusunan program pengawasan, pelaksanaan pembinaan pemantauan pelaksanaan 8 (delapan) Standar Nasional Pendidikan, penilaian, pembimbingan dan pelatihan professional Guru, evaluasi hasil pelaksanaan program pengawasan, dan pelaksanaan tugas kepengawasan di daerah khusus.

Selain dari hal di atas, dalam tugas keseharian pengawas madrasah harus menjalin komunikasi yang baik dengan guru dan kepala madrasah. Hal itu akan memudahkan pengawas madrasah memberikan informasi kedinasan. Selain itu citra dan kepemimpinan pengawas madrasah ketika melakukan pembinaan dan pembimbingan mempengaruhi kinerja guru. Kepemimpinan pengawas madrasah yang baik dapat memberikan kontribusi positif bagi kemajuan guru dan lembaga pendidikan madrasah yang dibinanya. Sebaliknya, kepemimpinan pengawas yang otoriter dan kaku saat melakukan pembinaan kemungkinannya bisa menimbulkan kondisi kerja yang kurang kondusif. Tentu saja tiap pengawas madrasah menggunakan metode dan punya gaya kepemimpinan yang berbeda dalam melakukan pembinaan terhadap guru PAI atau guru mata pelajaran umum lainnya di madrasah.

Kemampuan pengawas madrasah mengimplementasikan peningkatan mutu pendidikan di wilayah kerja binaannya adalah suatu keharusan, disamping perannya sebagai konsultan pendidikan. Ketika membina dan memantau aktivitas guru madrasah (khususnya guru PAI) mengajar, pengawas madrasah sebaiknya bersikap demokratis.

Kepekaan dan kepedulian pengawas madrasah dibutuhkan guru madrasah, khususnya guru PAI. Sementara ini masih ada keluhan para guru terhadap pengawas madrasah yang kurang profesional dalam melaksanakan tugas, terutama dalam 
melakukan supervisi pengajaran di madrasah. Misalnya, ketika melakukan pembimbingan pembuatan persiapan mengajar yang baik sesuai regulasi terkini, atau pembimbingan pembuatan media pembelajaran PAI berbasis $\mathrm{ITI}$, seperti menggunakan power point dan animasi, pembimbingan penyusunan programprogram madrasah, terutama dalam pembimbingan penyusunan program peningkatan keimanan dan ketaqwaan (imtaq).

Guru PAI diharapkan memiliki beberapa kompetensi, seperti dalam Peraturan Menteri Pendidikan Nasional Republik Indonesia Nomor 16 Tahun 2007 tentang Standar Kualifikasi Akademik dan Kompetensi Guru dinyatakan, Kompetensi Guru mata pelajaran Pendidikan Agama pada SD/MI, SMP/MTs, dan SMA/MA, SMK/MAK pada nomor 1.1. Kompetensi Guru PAI:

- Menginterpretasikan materi, struktur, konsep, dan pola pikir ilmu-ilmu yang relevan dengan pembelajaran Pendidikan Agama Islam.

- Menganalisis materi, struktur, konsep, dan pola pikir ilmu-ilmu yang relevan dengan pembelajaran Pendidikan Agama Islam.

Untuk mendukung kompetensi guru PAI diatas peran pengawas masih dibutuhkan. Artinya, pengawas madrasah secara langsung maupun tidak langsung memberikan pembinaan dan pembimbingan terhadap guru PAl secara profesional. Tentunya kepemimpinan pengawas dalam membina dan membimbing disesuaikan dengan situasi dan kondisi.

Berdasarkan hal tersebut, menarik peneliti untuk mengkaji dan menganalisis, bagaimana persepsi guru PAl terhadap Kepemimpinan Pengawas Madrasah?

Dengan demikian, tujuan penelitian ini untuk mendeskripsikan persepsi guru PAI terhadap kepemimpinan pengawas madrasah.

Mengingat luasnya jangkauan penelitian tentang persepsi guru madrasah, maka pada kesempatan ini peneliti membatasi kajian dan analisis tentang persepsi guru PAI di wilayah binaan (MTs. Negeri 5 dan 38, MTs Swasta Al Wathoniyah 14 dan 43) Kota Jakarta Utara Provinsi DKI Jakarta terhadap pengawas madrasah.

\section{KAJIAN TEORI}

\section{Persepsi}

Definisi persepsi dapat dilihat dari definisi secara etimologis maupun definisi yang diberikan oleh beberapa orang ahli. Secara etimologis, persepsi berasal dari kata perception (Inggris), dan dari kata Latin percipareyang artinya menerima atau mengambil. Menurut James Drever (Drever, $\underline{1988,338)}$ ) dalam "Kamus Psikologi", persepsi diartikan sebagai proses untuk mengingat atau mengidentifikasikan sesuatu.

John M. Ivancevich, Robert Konopaske dan Michael T. Matteson (Ivancevich, Konopaske, \& Matteson, 2006, 116) persepsi sebagai proses kognitif di mana seorang individu memilih, mengorganisasikan, dan memberi arti kepada stimulus lingkungan. Melalui persepsi, individu (Mr. B misalnya) berusaha untuk merasionalisasikan lingkungan dan objek, orang, dan peristiwa di dalamnya.

Tak jauh berbeda dengan definisi di atas, Robert Kreitner \& Angelo Kinicki (Kreitner \& Kinicki, 2003, 208) mengungkapkan bahwa persepsi adalah proses kognitif yang memungkinkan kita dapat menafsirkan. dan memahami lingkungan sekitar kita. Pengenalan benda-benda merupakan salah satu dari fungsi utama proses ini.

Menurut Lee \& Kotler (2011:198) dalam Alex Maulana Muqarrabin (2017), bahwa theory of reason action yang dikembangkan oleh Ajzen dan Fishbein, menyatakan bahwa prediksi terbaik mengenai perilaku seseorang adalah berdasarkan minat orang tersebut. Minat perilaku didasari oleh 2 faktor utama yaitu: kepercayaan individu atas hasil dari perilaku yang dilakukan dan persepsi individu atas pandangan orang-orang terdekat individu terhadap perilaku yang dilakukan.

Sedangkan Fred Luthans dalam bukunya Perilaku Organisasi Edisi Sepuluh (Luthan, 2006, 194 \& 197) persepsi merupakan proses kognitif kompleks yang menghasilkan gambaran dunia yang unik, yang mungkin agak berbeda dari realita. Sedangkan pada bagian lain, dijelaskan bahwa proses persepsi atau filter dapat didefinisikan sebagai interaksi seleksi, organisasi, dan interpretasi yang rumit. Persepsi sangat tergantung pada indera untuk data mentah, dan proses kognitif menyaring, 
memodifikasi, atau sepenuhnya mengubah data tersebut.

Pengalaman seseorang itu bisa langsung maupun tidak langsung. Misalnya seseorang yang tiap hari pergi dan pulang kerja selalu mengalami kemacetan di jalan-jalan kota Jakarta, atau seseorang mendengarkan kisah kemacetan dari sahabatnya atau melihat berita kemacetan kota Jakarta melalui televisi dan radio, maka seseorang itu memiliki persepsi tentang kota Jakarta yang semrawut dan macet diman-mana. Atau pada saat menulis penelitian ini di awal tahun 2020 terjadi wabah virus corona yang cepat penularannya. Tiap hari televisi atau media onlines menyiarkan berita wabah virus corona yang menjarah hampir seluruh dunia, dan tiap orang harus mengantisipasi melakukan pertahanan diri sendiri dengan menggunakan masker jika keluar rumah, menjaga jarak aman dan selalu mencuci tangan dengan sabun atau sanitizer; maka berbondong-bondong orang membeli masker sehingga harga masker melambung tinggi. Muncul spekulan-spekulan dan penimbun masker. Juga penyemprotan cairan disinfektan ditempat-tempat yang sering dikunjungi orang, seperti pasar atau mesjid marak dilakukan, bahkan pada saat datang ke mesjid jamaah membawa sajadah sendiri. Bahkan salat Idul Fitri $1441 \mathrm{H}$. dilakukan di rumah masing-masing. Kondisi berita yang terus menerus di televisi, radio atau media onlines tersebut, sehingga ada persepsi bahwa virus sangat-sangat kecil tersebut siap menerkam siapa saja tanpa pandang bulu.

Dengan demikian, dapat disimpulkan bahwa persepsi merupakan proses kognitif, dimana seseorang menafsirkan informasi yang diterima melalui alat indera dan diteruskan ke otak untuk diseleksi dan diorganisasikan, sehingga menimbulkan penafsiran atau penilaian terhadap pengalaman atau lingkungannya.

Sedangkan yang dimaksud guru menurut Peraturan Menteri Pendayagunaan Aparatur Negara dan Reformasi Birokrasi Nomor 16 Tahun 2009 tentang Jabatan Fungsional Guru dan Angka Kreditnya, Bab I Pasal 1 ayat 1 yaitu: guru adalah pendidik profesional dengan tugas utama mendidik, mengajar, membimbing, mengarahkan, melatih, menilai dan mengevaluasi peserta didik pada pendidikan anak usia dini jalur pendidikan formal, pendidikan dasar dan pendidikan menengah.

Dalam Lampiran Peraturan Menteri Agama Nomor 2 tahun 2008 tentang Standar Kompetensi Lulusan Mata Pelajaran Agama Islam dan bahasa Arab di madrasah Bab I yaitu: Standar Kompetensi Lulusan PAI dan Bahasa Arab pada madrasah meliputi: Alquran Hadis, Akidah Akhlak, Fikih, Sejarah Kebudayaan Islam, dan Bahasa Arab. Jadi, guru PAI pada madrasah adalah para guru yang mengajar Alquran Hadis, Akidah Akhlak, Fikih, Sejarah Kebudayaan Islam, dan Bahasa Arab. Dengan demikian, persepsi guru PAI adalah persepsi guru yang mengajar mata pelajaran Alquran Hadis, Akidah Akhlak, Fikih, Sejarah Kebudayaan Islam, dan Bahasa Arab di madrasah (dalam hal ini di Madrasah Tsanawiyah) terhadap pengawas madrasah.

Dengan demikian persepsi adalah proses pengolahan informasi dari lingkungan yang berupa stimulus, yang diterima melalui alat indera dan diteruskan ke otak untuk diseleksi dan diorganisasikan, sehingga menimbulkan penafsiran atau penginterpretasian yang berupa penilaian dari penginderaan atau pengalaman sebelumnya. Jadi, persepsi merupakan hasil interaksi antara dunia luar individu (lingkungan) dengan pengalaman individu yang sudah diinternalisasi dengan sistem sensorik alat indera sebagai penghubung, dan dinterpretasikan oleh system syaraf di otak.

\section{Kepemimpinan}

Bagi seorang pengawas madrasah, memiliki gaya kepemimpinan yang dapat diterima oleh semua guru (binaannya) penting. Hal itu akan sangat menentukan berhasil tidaknya pengawas madrasah dalam membina guru selanjutnya. Kepemimpinan pengawas madrasah mempengaruhi para guru, sehingga mereka mau bekerjasama dalam rangka mewujudkan tujuan pendidikan yang bermutu. Kepemimpinan seorang pengawas madrasah di wilayah binaannya merupakan salah satu motivasi para guru PAI untuk berprestasi atau bekerja secara profesional. Berikut beberapa definisi kepemimpinan. 
Stephen P. Robbins dan Timothy A. Judge (Robbins \& Judge, 2008, 49) mendefinisikan kepemimpinan (leadership) sebagai kemampuan untuk mempengaruhi suatu kelompok guna mencapai sebuah visi atau serangkaian tujuan yang ditetapkan. Pada bagian lain Robbins dan Judge, menjelaskan tentang teori sifat kepemimpinan (trait theories of leadership) yang membedakan para pemimpin dari mereka yang bukan pemimpin dengan cara berfokus pada berbagai sifat dan karakteristik pribadi. Jika kita amati para tokoh atau pemimpin nasional Indonesia, seperti presiden Republik Indonesia yang telah memimpin Indonesia banyak karakter yang dapat kita simak, sebagai contoh Presiden pertama Soekarno yang kharismatik dan memiliki kemampuan berpidato yang berapi-api dan membangkitkan semangat juang bagi bangsa Indonesia. Presiden kedua Soeharto yang selalu memperlihatkan mimik tersenyum jika berpidato atau bertemu dengan masyarakat kelompok tani (misalnya). Beliau terkesan merakyat saat berhadapan dengan masyarakat. Presiden Habibi yang antusias, berani dan penuh semangat jika berpidato atau berdiskusi. Susilo Bambang Yudoyono (SBY) yang simpatik dan melankolik serta tertata jika berpidato, dan seterusnya. Tentu saja kita bisa belajar dari para pemimpin tersebut jika ingin berhasil memimpin.

Sedangkan Dale Timpe dalam bukunya Kepemimpinan (The Art and Science of Business Management Leadership) (Timpe, 1991, 58 \& 60), menjelaskan kepemimpinan adalah proses pengaruh sosial di mana manajer mencari keikutsertaan sukarela dari bawahan dalam usaha mencapai tujuan organisasi. Pada bagian lain dijelaskan, bahwa riset kepemimpinan masa kini semuanya bersifat stuasional. Pendekatan ini mempelajari keterkaitan antara perilaku atau ciri pemimpin dan bawahan serta situasi dimana kedua pihak itu berada.

House et.al., dalam Gary Yukl (Yukl, 2007. 4 \& 98), "kepemimpinan adalah kemampuan individu untuk mempengaruhi, memotivasi, dan membuat orang lain mampu memberikan kontribusinya demi efektivitas dan keberhasilan organisasi...". Sedangkan pada bagian lain Gary Yukl , menjelaskan bahwa Kepemimpinan
Partisipatif menyangkut penggunaan berbagai macam prosedur keputusan yang memberi orang lain pengaruh tertentu terhadap keputusan pemimpin tersebut. Istilah lainnya yang biasa digunakan untuk menyebut aspek kepemimpinan partisipatif mencakup konsultasi, pengambil keputusan bersama, pembagian kekuasaan, desentralisasi dan manajemen yang demokratis.

Selain kepemimpinan situasional, ada teori ketergantungan pada keadaan (teori Contingency), Yayat Hayati Djatmiko (Djatmiko, 2005, 51) menjelaskan, inti pemikiran yang terkandung dalam teori Contingency ini ialah bahwa efektivitas kepemimpinan seseorang dalam suatu organisasi sangat tergantung pada kemampuan menyesuaikan gaya kepemimpinan yang menjadi karakteristik utamanya dengan tuntutan pelaksanaan tugas yang harus terselenggara dalam oraganisasi.

Dengan demikian kepemimpinan merupakan suatu usaha mempengaruhi orang lain, baik secara perseorangan maupun kelompok.

Seperti diutarakan sebelumnya, bahwa pengawas madrasah mempunyai tugas, tanggung jawab dan wewenang untuk melaksanakan pengawasan akademik dan manajerial pada satuan pendidikan. Tentu saja ketika melakukan supervisi akademik maupun supervisi manajerial, pengawas madrasah harus menjalin kerja sama dengan para guru PAI binaannya. Komunikasi yang kurang harmonis tidak jarang menyebabkan informasi - informasi kedinasan atau regulasi pendidikan penyampaiannya tersendat-sendat. Padahal semua pihak menginginkan madrasah maju dan sejajar dengan lembaga - lembaga pendidikan formal lainnya.

William A. Pasmore (Pasmore, 1994, 5) mengatakan bahwa the ability of organization to respond to further change, semestinya madrasah tidak tertinggal dengan lembagalembaga pendidikan formal lainnya. Banyak perkembangan dan perubahan lingkungan yang dapat direspon madrasah. Meskipun, masih ada pimpinan madrasah yang kurang peka dengan perkembangan zaman. Kondisi demikian, dibutuhkan peran pengawas madrasah untuk memotivasi dan membimbing madrasah 
tersebut untuk menyesuaikan diri dengan keinginan masyarakat atau sesuai harapan semua pihak.

Dengan demikian, seorang pengawas madrasah dengan gaya kepemimpinannya diharapkan memiliki kemampuan membina dan membimbing bahkan sebagai konsultan pendidikan yang memiliki gagasan-gagasan up to date kepada para guru dan kepala madrasah yang menjadi wewenang tanggung jawabnya, dan hal itu mendorong munculnya gagasan baru lainnya dari guru atau kepala madrasah.

Sinergitas pengawas dengan guru madrasah sangat diperlukan. Pengawas yang berpengalaman membina para guru madrasah tentunya selalu menjalin hubungan yang harmonis antara pembina dengan orang atau pihak-pihak yang dibinanya. Ketika membina guru dan lembaga madrasah pengawas yang sudah lama bertugas tidak hanya menggunakan satu gaya kepemimpinan saja; akan tetapi menggunakan berbagai gaya kepemimpinan sesuai situasi dan kondisi. Misalnya, gaya kepemimpinan demokratis, partisipatif, otokratik dan sebagainya. Berikut dijelaskan beberapa gaya kepemimpinan.

Kepemimpinan otokratik mempunyai makna atau pengertian yang hampir sama dengan teori yang dikemukakan oleh McGregor seperti yang dikutip Dubrin (Pasmore, 1994, 263) sebagai berikut the theory $X$ or autocratic, manager makes these assumptions about worker; people dislike work and must be coerced, controlled, and directed toward organisational goals, most people like to be treated this way so they Im avoid respon sibility. Kepemimpinan seperti ini lebih tepat digunakan pada organisasi yang masih baru dimana para pengawalnya masih baru dan belum mempunyai banyak pengalaman lapangan untuk melakukan tugas. Sebagai contoh, madrasah-madrasah yang baru berdiri dipimpin oleh kepala madrasah yang baru diangkat ataupun kepala madrasah yang belum berpengalaman, tetapi yang dihadapi adalah guru baru, maka kepemimpinan otoriter lebih tepat.

Dijelaskan oleh Gibb (Salusu, 1996, 203) ada empat unsur utama dalam kepemimpinan, yaitu: (1) pemimpin yang menampilkan kepribadian pemimpin, (2) kelompok, (3) pengikut yang muncul dengan berbagai kebutuhannya, sikap, serta masalahmasalahnya, dan (4) situasi, yang meliputi keadaan fisik dan tugas -kelompok. Keempat unsur tersebut akan mempengaruhi efektifitas kepemimpinan. Seorang pemimpin tergantung oleh kekuatan pada dirinya, kekuatan pada anggotanya dan kekuatan pada situasi. Keberhasilan seorang pemimpin karena adanya bantuan dari anggota yang dipimpinnya. Anggota tidak hanya bekerja untuk dirinya dalam kerangka kepentingan organisasi, tetapi mereka juga bekerja untuk memenuhi keinginan mereka sendiri.

Gatto (Gatto, 1992, 212) kemudian mencoba melengkapi empat gaya kepemimpinan, yaitu : gaya direktif, gaya konsultatif, gaya partisipatif, dan gaya delegasi. Pada gaya direktif, pada umumnya pemimpin membuat keputusan-keputusan penting dan terlibat di dalam pelaksanaannya. Pemimpin hanya memberi sedikit kebebasan pada orang lain untuk bertindak sesuai dengan izinnya. Gaya konsultatif, dibangun atas gaya direktif, tetapi kurang otoriter. Pemimpin lebih banyak melakukan interaksi dengan anggota organisasi.

Davis dan Newstroom (Newstroom \& Devis, 1999, 207) menambahkan penjelasan bahwa dua gaya kepemimpinan yang berbeda dapat diterapkan pada anggota kelompok, yaitu consideration dan structure yang juga dikenal sebagai gaya kepemimpinan yang berorientasi pada pekerja atau anggota dan gaya kepemimpinan yang berorientasi pada tugas atau pekerjaan. Seorang pemimpin yang berorientasi pada tugas akan mengarahkan dan mengawasi anggotanya secara tertutup untuk menjamin tugas diselesaikan sesuai dengan yang diharapkan. Pemimpin dengan gaya kepemimpinan ini lebih memperhatikan pelaksanaan pekerjaan daripada pengembangan dan pertumbuhan anggotanya.

Sedangkan seorang pemimpin yang berorientasi pada anggotanya, mencoba untuk memberikan motivasi dibandingkan dengan mengawasi mereka. Pemimpin mendorong para anggotanya untuk melaksanakan tugas dengan memberikan kesempatan berpartisipasi dalam pembuatan keputusan, menciptakan suasana kerja yang penuh persahabatan serta menjalin 
hubungan yang saling mempercayai dan menghormati dengan sesama anggota kelompok.

Blake dan Mouton dalam (Newstroom \& Devis, 1999, 209), dengan sistem misi manajerial (Managerial Grid), mengidentifikasikan selang perilaku manajemen atas dasar berbagai cara yang membuat gaya berorientasi kepada tugas dan gaya yang berorientasi pada karyawan atau anggota. Menurut Blake dan Mouton, perilaku manajemen ini masing-masing dinyatakan sebagai suatu rangkaian kesatuan pada skala 1 sampai 9 yang berinteraksi satu dengan yang lainnya. Gaya pemimpin 1.1 tergolong pemimpin dengan perhatian rendah terhadap orang dan rendah terhadap tugas. Gaya pemimpin 1.9 adalah kekeluargaan (perhatian tinggi pada anggota), tetapi rendah perhatian terhadap tugas. Gaya pemimpin 9.1 gaya otoriter, yaitu perhatian tinggi pada tugas tetapi rendah pada anggota. Gaya 5.5 adalah gaya manajemen jalan tengah baik terhadap orang maupun terhadap tugas. Gaya 9.9 adalah demokratis, perhatian tinggi, baik terhadap tugas maupun orang.

Berdasarkan uraian di atas, terdapat gaya kepemimpinan yang menonjol yaitu demokratis, partisipatif, dan otokratik. Sebagai seorang pengawas madrasah di dalam mempengaruhi aktivitas guru-guru madrasah yang menjadi binaannya, dapat menerapkan berbagai gaya kepemimpinan yang sesuai dengan situasi kepemimpinan yang dihadapi. Untuk mewujudkan tujuan yang ingin dicapai, maka seorang pengawas madrasah dapat menerapkan gaya kepemimpinan yang akan disesuaikan dengan : (1). Visi yang dianut oleh pengawas madrasah sebagai pembina pendidikan, (2). Pemahamannya terhadap kondisi guru yang menjadi bawahan, dan (3). Wawasan tentang kepemimpinannya.

Jadi yang dimaksud gaya kepemimpinan adalah suatu pola perilaku kepemimpinan yang ditampilkan oleh seorang pemimpin pada saat mempengaruhi aktivitas orang lain dalam suatu organisasi.

Sedangkan penelitian yang relevan tentang kepemimpinan seperti yang dilakukan oleh Hanifah, Novi Indah Susanti dan Agus Setiawan dalam penelitiannya tentang "The Effect of
Leadership Style on Motivation to Improve The Employee Performance" ", bahwa gaya kepemimpinan dapat mempengaruhi kinerja karyawan (PT Pelni). Namun pengaruh motivasi terhadap kinerja lebih kuat bila dibandingkan gaya kepemimpinan terhadap kinerja karyawan tersebut.

Penelitian relevan lain yang salah satu variabelnya gaya kepemimpinan yaitu yang dilakukan Hindun Anwar (Anwar, 2012) dengan judul "Korelasi antara Motivasi Berprestasi $\left(\mathrm{X}_{1}\right)$ dan Penilaian Pengawas Terhadap Gaya Kepemimpinan Kepala Kementerian Agama Kota Jakarta Pusat $\left(X_{2}\right)$ dengan Kinerja Pengawas Madrasah $(Y)^{\prime \prime}$, dengan hasil sebesar 0,44 adalah sangat signifikan. Ini berarti terdapat hubungan positif antara Penilaian Pengawas Terhadap Gaya Kepemimpinan Kepala Kementerian Agama Kota Jakarta Pusat $\left(\mathrm{X}_{2}\right)$ dengan Kinerja Pengawas Madrasah $(\mathrm{Y})$; atau dengan perkataan lain, makin baik penilaian pengawas terhadap gaya kepemimpinan Kepala Kementerian Agama Kota Jakarta Pusat, maka makin tinggi Kinerja Pengawas Madrasah.

Penelitian yang dilakukan Hindun Anwar pada tahun 2012 dengan salah satu variable sama dengan penelitian yang dibahas disini yaitu gaya kepemimpinan Kepala Kantor Kementerian Agama; namun penelitian Hindun Anwar berbeda lokasi dan sasarannya dengan yang dilakukan peneliti saat ini, tertutama dalam metodologi analisis data yang diolah, yaitu menggunakan metode deskriftif korelasional kuantitatif.

Adapun kajian penelitian ini yaitu tentang persepsi guru PAl terhadap kepemimpinan pengawas madrasah di wilayah binaan pengawasan Kota Jakarta Utara Provinsi DKI Jakarta. Selain itu, tugas pokok pengawas sangat berbeda karakternya dengan kepala kantor kementerian agama. Pengawas bertugas sebagai pembina dan pembimbing guru, kepala madrasah dan tenaga kependidikan di lingkup kerja dari beberapa satuan pendidikan madrasah yang lebih kecil, baik dari sumber daya manusia maupun sarana dan prasarana, apalagi dari segi pembiayaan. Sedangkan Kepala Kantor Kementerian Agama memiliki unit kerja yang lebih luas dan sarana prasarana lebih besar dan tentunya pembiayaan 
operasional kantor Kementerian Agama Kota lebih besar.

\section{MOTODE PENELITIAN}

\section{Metode Penelitian}

Metode penulisan penelitian ini mixed method (kombinasi metode kuantitatif dan kualitatif). Menurut John W Creswell (Creswell, 2014) dalam Tri Rahmah Silviani (2015) penelitian metode campuran (mixed method) merupakan pendekatan penelitian yang mengkombinasikan atau mengasosiasikan bentuk kualitatif dan bentuk kuantitatif. Pendekatan ini melibatkan asumsi-asumsi filosofis, aplikasi pendekatan-pendekatan kualitatif dan kuantitatif, dan campuran (mixing) kedua pendekatan tersebut dalam satu penelitian.

Mixed mithod dalam penelitian ini menggunakan strategi triangulasi konkuren , yaitu menerapkan satu tahap pengumpulan data kuantitatif dan kualitatif dalam satu waktu. Bobot antara data kuantitatif dan kualitatif seimbang; atau dengan kata lain pencampuran dua data terjadi ketika hasil-hasil data yang dikomparasikan pada bagian pembahasan.

Untuk data kualitatif didukung dengan wawancara tentang persepsi guru PAI terhadap Kepemimpinan Pengawas madrasah. Menurut Lexy J. Moleong (Moleong, 2007) metode kualitatif adalah penelitian yang bermaksud untuk memahami fenomena tentang apa yang dialami oleh subjek penelitian, misalnya perilaku, persepsi, motivasi, tindakan, dll.

\section{Populasi dan Sampel}

Menurut Suharsimi Arikunto (Arikunto, 2010, 173), Populasi yaitu keseluruhan subjek penelitian. Sedangkan menurut Sugiyono (Sugiyono, 2012, 80) populasi adalah wilayah generalisasi yang terdiri atas: objek/subjek yang mempunyai kualitas dan karakteristik tertentu yang ditetapkan oleh peneliti untuk dipelajari dan kemudian ditarik kesimpulannya. Populasi penelitian ini adalah seluruh guru PAI pada MTs. Negeri 5 dan 38, MTs Swasta Al Wathoniyah 14 dan 43 di wilayah Kota Jakarta Utara. dan sampel penelitian dalam makalah ini adalah Guru Madrasah Tsanawiyah (MTs), baik negeri maupun swasta di Kota Jakarta Utara; yaitu:

Tabel 1. Jumlah Guru PAI

\begin{tabular}{|c|c|c|}
\hline No & Nama MTs. & Jlh Guru PAI \\
\hline 1. & MTs. Negeri 5 & 10 orang \\
\hline 2. & MTs. Negeri 38 & 10 orang \\
\hline 3. & $\begin{array}{l}\text { MTs. Swasta Al } \\
\text { Wathoniyah } 14\end{array}$ & 6 orang \\
\hline 4. & $\begin{array}{ll}\text { MTs. Swasta } & \text { Al } \\
\text { Wathonoyah } 43\end{array}$ & 6 orang \\
\hline & Jumlah & 32 orang \\
\hline
\end{tabular}

Menurut Sugiyono (Sugiyono, 2012, 57), Sampel adalah sebagian dari jumlah dan karakteristik yang dimiliki oleh populasi tersebut. Namun penentuan sampel pada penulisan penelitian ini adalah semua anggota populasi digunakan sebagai sampel. Hal itu dilakukan karena jumlah populasi relatif kecil. Menurut Sugiono (Sugiyono, 2012, 62), sampling jenuh, adalah teknik penentuan sampel bila semua anggota populasi digunakan sebagai sampel.

\section{Teknik Pengumpulan Data dan Pengembangan Instrumen.}

Teknik pengumpulan data menggunakan instrumen atau angket Skala Likert dengan pernyataan 4 (empat). Menurut Sugiyono (Sugiyono, 2012, 93) Skala Likert digunakan untuk mengukur sikap, pendapat dan persepsi seseorang atau kelompok orang tentang fenomena sosial. Instrumen dibuat berdasarkan pengembangan teori.

Dalam satu waktu dilakukan juga wawancara terhadap responden. Wawancara yang dilakukan adalah wawancara terstruktur. Menurut Sugiyono (Sugiyono, 2012, 233) wawancara terstruktur digunakan sebagai teknik pengumpulan data, bila peneliti telah mengetahui dengan pasti tentang informasi apa yang akan diperoleh.

Wawancara pada penelitian ini dilakukan terhadap $20 \%$ dari jumlah 32 responden, yaitu 6 orang guru PAl; dengan rincian sebagai berikut. 
Tabel 2. Jumlah Guru PAI yang Diwawancarai

\begin{tabular}{|c|c|c|}
\hline No & $\begin{array}{c}\text { Jumlah Guru PAI MTs } \\
\text { yang Diwawancarai } \\
(20 \%)\end{array}$ & $\begin{array}{c}\text { Jumlah } \\
\text { Guru }\end{array}$ \\
\hline 1. & $\begin{array}{l}\text { MTs. Negeri 5: } 10 \text { org X } 20 \% \\
=2 \text { orang }\end{array}$ & 2 orang \\
\hline 2. & $\begin{array}{l}\text { MTs. Negeri 38: } 10 \text { org } X \\
20 \%=2 \text { orang }\end{array}$ & 2 orang \\
\hline 3. & $\begin{array}{l}\text { MTs. Al Wathoniyah 14: } 5 \\
\text { org X } 20 \%=1 \text { orang }\end{array}$ & 1 orang \\
\hline 4. & $\begin{array}{l}\text { MTs. Al Wathoniyah } 43: 5 \\
\text { org X } 20 \%=1 \text { orang }\end{array}$ & 1 orang \\
\hline & Jumlah & 6 orang \\
\hline
\end{tabular}

\section{Teknik Analisis Data}

Menurut Sugiyono (Sugiyono, 2012, 104), analisis data merupakan upaya menerjemahkan secara sistematis dari hasil pengumpulan data untuk meningkatkan pemahaman terhadap obyek yang sedang diteliti. Data dalam penelitian ini adalah campuran data kuantitatif dan data kualitatif.

Untuk pengukuran keabsahan data pada penelitian ini dilakukan dengan triangulasi. Menurut Sugiyono (Sugiyono, 2012, 241) Data yang telah diperoleh terlebih dahulu dianalisa agar dapat dipergunakan untuk menjawab rumusan masalah yang telah ditetapkan.

Data kuantitatif dari hasil angket terbuka dideskripsikan dengan cara dikomulatifkan, kemudian dianalisis dan dicari skor nilai ratarata pada tiap item pernyataan. Atau dengan kata lain, data kuantitatif pada penelitian ini dianalisa menggunakan analisis deskriptif dengan rumus persentase; yaitu:

Jumlah skor perolehan X $100 \%$. Jumlah skor maksimal.

Data kualitatif hasil wawancara dikumpulkan kemudian dianalisis. Selanjutnya dari hasil kedua data kualitatif dan kuantitatif dikomparasikan untuk dicari titik persamaan kesimpulannya.

\section{Tempat dan waktu}

Seperti telah diutarakan diatas, bahwa sasaran penelitian adalah guru PAI MTs Negeri 5, MTs. Negeri 38, MTs. Swasta Al Wathoniyah 14, MTs. Swasta Al Wathoniyah 43, semuanya di Kota Jakarta Utara Propinsi DKI Jakarta. Waktu penelitian selama 3 bulan terhitung bulan Oktober s/d Desember 2019.

\section{TEMUAN DAN PEMBAHASAN}

\section{Temuan}

Untuk menjaring informasi/data dalam penulisan makalah ini adalah dengan cara menyebarkan questioner kepada responden (guru-guru PAI MTs) yang bisa dilihat dalam table di bawah ini.

Tabel 3. Persepsi Guru PAI terhadap Gaya Kepemimpinan Pengawas

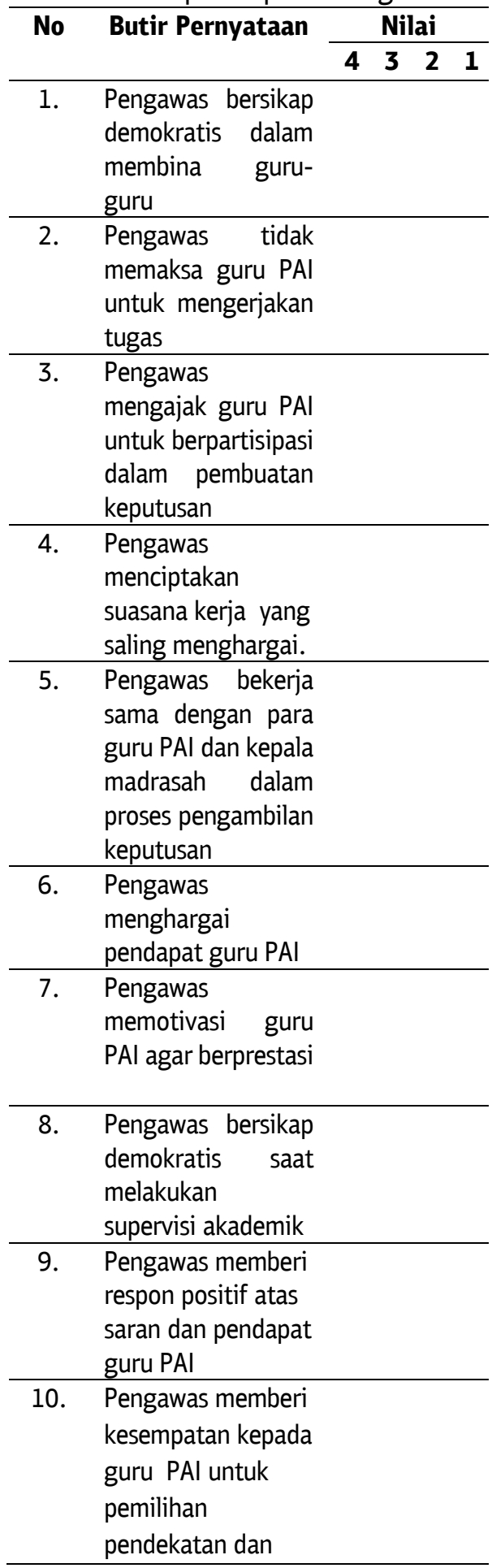




\begin{tabular}{l}
\hline $\begin{array}{l}\text { media } \\
\text { pembelajaran PAI } \\
\text { yang tepat }\end{array}$ \\
\hline Keterangan: \\
Skor 1 = sangat tidak setuju \\
Skor 2 = tidak setuju \\
Skor 3 = setuju \\
Skor 4 = sangat setuju
\end{tabular}

Tabel 4. Hasil Persepsi Guru terhadap Gaya Kepemimpinan Pengawas

\begin{tabular}{|c|c|c|c|}
\hline No & Butir Pernyataan & Skor & Ket \\
\hline 1. & $\begin{array}{l}\text { Pengawas bersikap } \\
\text { demokratis dalam } \\
\text { membina guru-guru }\end{array}$ & 85,00 & $B$ \\
\hline 2. & $\begin{array}{l}\text { Pengawas tidak } \\
\text { memaksa guru PAI } \\
\text { untuk mengerjakan } \\
\text { tugas }\end{array}$ & 77,5 & $B$ \\
\hline 3. & $\begin{array}{lr}\text { Pengawas mengajak } \\
\text { guru PAI untuk } \\
\text { berpartisipasi } & \text { dalam } \\
\text { pembuatan } & \\
\text { keputusan } & \\
\end{array}$ & 75 & $B$ \\
\hline 4. & $\begin{array}{l}\text { Pengawas } \\
\text { menciptakan suasana } \\
\text { kerja yang saling } \\
\text { menghargai. }\end{array}$ & 79,166 & $B$ \\
\hline 5. & $\begin{array}{l}\text { Pengawas bekerja } \\
\text { sama dengan para } \\
\text { guru PAI dan kepala } \\
\text { madra- sah dalam } \\
\text { proses pengam- bilan } \\
\text { keputusan }\end{array}$ & 82,500 & $B$ \\
\hline 6. & $\begin{array}{l}\text { Pengawas } \\
\text { menghargai } \\
\text { pendapat guru PAI }\end{array}$ & 80,833 & $B$ \\
\hline 7. & $\begin{array}{l}\text { Pengawas } \\
\text { memotivasi guru PAI } \\
\text { agar berprestasi }\end{array}$ & 79,166 & $B$ \\
\hline 8. & $\begin{array}{lr}\text { Pengawas } & \text { bersikap } \\
\text { demokratis } & \text { saat } \\
\text { melakukan } & \text { supervisi } \\
\text { akademik } & \\
\end{array}$ & 80,833 & $B$ \\
\hline 9. & $\begin{array}{l}\text { Pengawas memberi } \\
\text { respon positif atas } \\
\text { saran dan pendapat } \\
\text { guru PAl }\end{array}$ & 76,666 & $B$ \\
\hline 10 & $\begin{array}{l}\text { Pengawas memberi } \\
\text { kesempatan kepada } \\
\text { guru PAI untuk }\end{array}$ & 82,5 & $B$ \\
\hline
\end{tabular}

\begin{tabular}{lll}
\hline $\begin{array}{l}\text { pemilihan } \\
\text { pendekatan dan } \\
\text { media pembelajaran } \\
\text { PAl yang tepat }\end{array}$ & & \\
\hline Total skor & 799,16 & \\
\hline Nilai Rata-rata & $\mathbf{7 9 , 9 1 6}$ & B \\
\hline
\end{tabular}

Keterangan: Skor nilai rata - rata $=\mathbf{7 9 , 9 1 6}$

( kategori Baik ). Nilai 10 (sepuluh) item pernyataan Persepsi Guru PAI MTs. terhadap Kepemimpinan Pengawas dapat dilihat dalam gambar histogram berikut ini.

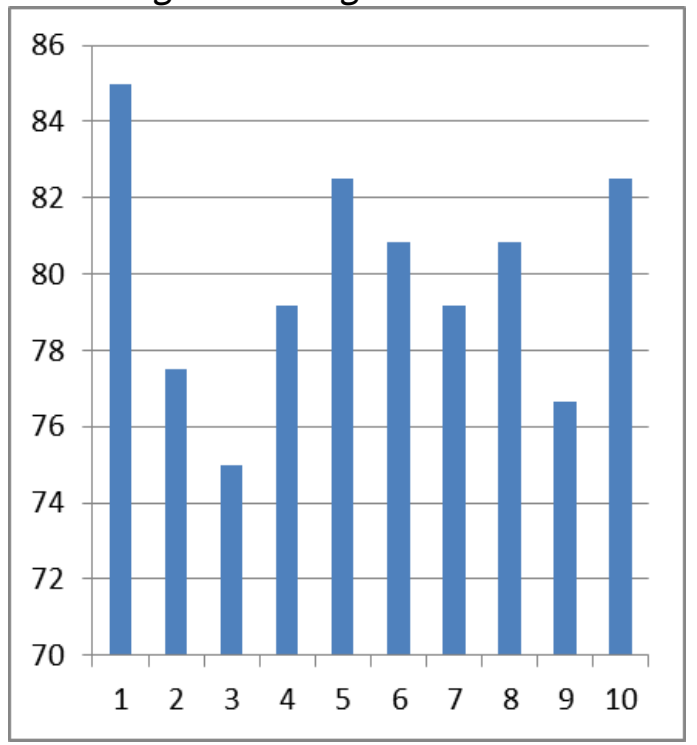

Gambar 1. Histogram Nilai Tiap Pernyataan Persepsi Guru PAI terhadap Kepemimpinan Pengawas

Hasil analisis item pernyataan persepsi guru PAI MTs terhadap kepemimpinan pengawas madrasah pada nomor 1 yaitu "Pengawas bersikap demokratis dalam membina guruguru" diperoleh skor nilai 85,00. Artinya, hasil penilaian 32 orang guru PAI MTs diperoleh nilai rata-rata sebesar 85,00 dengan predikat baik.

Hasil analisis item pernyataan persepsi guru PAI MTs terhadap kepemimpinan pengawas madrasah pada nomor 2 yaitu "Pengawas memberikan pengarahan terlebih dulu sebelum memberi tugas kepada guru PAI “ diperoleh skor nilai 77,5. Artinya, hasil penilaian 32 orang guru PAI diperoleh nilai rata-rata sebesar 77,5 dengan predikat baik.

Hasil analisis item pernyataan persepsi guru PAI MTs terhadap kepemimpinan pengawas madrasah pada nomor 3 yaitu "Pengawas 
memberi kesempatan berpartisipasi dalam pembuatan keputusan" diperoleh skor nilai 75 . Artinya, hasil penilaian 32 orang guru PAI MTs diperoleh nilai rata-rata sebesar 75 dengan predikat baik.

Hasil analisis item pernyataan persepsi guru PAI MTs terhadap kepemimpinan pengawas madrasah pada nomor 4 yaitu "Pengawas menciptakan suasana kerja penuh persahabatan dan saling mempercayai" diperoleh skor nilai 79,166. Artinya, hasil penilaian 32 orang guru PAI MTs diperoleh nilai rata-rata sebesar 79,166 dengan predikat baik.

Hasil analisis item pernyataan persepsi guru PAI MTs terhadap kepemimpinan pengawas madrasah pada nomor 5 yaitu "Pengawas mau bekerja sama dengan para guru PAI dan kepala madrasah dalam proses pengambilan keputusan" diperoleh skor nilai 82,500. Artinya, hasil penilaian 32 orang guru PAI MTs diperoleh nilai rata-rata sebesar 82,500 dengan predikat baik.

Hasil analisis item pernyataan persepsi guru PAI MTs terhadap kepemimpinan pengawas madrasah pada nomor 6 yaitu "Pengawas menghormati tiap pendapat orang lain" diperoleh skor nilai 80,833 . Artinya, hasil penilaian 32 orang guru PAI MTs diperoleh nilai rata-rata sebesar 80,833 dengan predikat baik.

Hasil analisis item pernyataan persepsi guru PAI MTs terhadap kepemimpinan pengawas madrasah pada nomor 7 yaitu "Pengawas menghargai prestasi guru PAl" diperoleh skor nilai 79,166. Artinya, hasil penilaian 32 orang guru PAI MTs diperoleh nilai rata-rata sebesar 79,166 dengan predikat baik.

Hasil analisis item pernyataan persepsi guru PAI MTs terhadap kepemimpinan pengawas madrasah pada nomor 8 yaitu "Pengawas kooperatif ketika pengawas PAI melakukan supervisi akademik (kunjungan kelas)" diperoleh skor nilai 80,833. Artinya, hasil penilaian 32 orang guru PAI MTs diperoleh nilai rata-rata sebesar 80,833 dengan predikat baik.

Hasil analisis item pernyataan persepsi guru PAI MTs terhadap kepemimpinan pengawas madrasah pada nomor 9 yaitu "Pengawas memberi respon positif atas saran dan pendapat guru PAI," diperoleh skor nilai 76,666. Artinya, hasil penilaian 32 orang guru PAI MTs diperoleh nilai rata-rata sebesar 76,666 dengan predikat baik.

Hasil analisis item pernyataan persepsi guru PAI MTs terhadap kepemimpinan pengawas madrasah pada nomor 10 yaitu "Pengawas memberi kesempatan kepada guru untuk pemilihan pendekatan dan media pembelajaran PAl yang tepat" diperoleh skor nilai 76,666. Artinya, hasil penilaian 32 orang guru PAI MTs diperoleh nilai rata-rata sebesar 76,666 dengan predikat baik.

Berdasarkan analisis 10 (sepuluh) item pernyataan tentang persepsi guru PAI MTs terhadap kepemimpinan pengawas madrasah diperoleh nilai rata-rata sebesar 79,916 (Baik).

Selain penyebaran angket kepada responden (guru PAI MTs di Wilayah Binaan Kota Jakarta Utara), penulis juga melakukan wawancara yang dipilih secara acak dari tiaptiap MTs Negeri maupun MTs Swasta binaan sebanyak $20 \%$; sehingga diperoleh responden sebanyak 6 orang; yaitu 2 orang perwakilan dari guru PAI pada MTs. Negeri 5, 2 orang perwakilan dari guru PAI pada MTs. Negeri 38, 1 orang perwakilan dari guru PAI pada MTs. Swasta Al Wathoniyah 14, dan 1 orang perwakilan dari guru PAI pada MTs. Swasta Al Wathoniyah 43.

Abdullah, (bukan nama sebenarnya) guru PAl pada MTs. Negeri 5 menjelaskan, "sejak diangkat menjadi guru Fikih, alhamdulillah saran dan pendapat saya dan para guru lainnya diterima pengawas madrasah. Bahkan ketika hendak menentukan model atau metode yang tepat sesuai materi yang saya ajarkan kepada siswa pengawas pun selalu memberi bimbingan dan menghargai pendapat para guru PAI."

$\mathrm{Hj}$. Maryam, guru SKI yang juga dari MTs. Negeri 5 menuturkan "sikap kepemimpinan pengawas madrasah yang membina kami cukup demokratis. Beliau selalu memusyawarahkan tiap kegiatan yang akan dilakukan dan melibatkan para guru dan para siswa. Begitu pula bila ada permasalahan yang muncul beliau pun meminta saran dan pendapat para guru. "

Siti Qomariyah, (bukan nama sebenarnya) yang telah bertugas sebagai guru Akidah Akhlak selama 15 tahun di MTs. Negeri 38 
mengungkapkan "sebagian besar sikap kepemimpinan pengawas saat melakukan tugas supervisi kepada kami demokratis dan menguasai bidangnya. Hal itu mendorong kami untuk bisa bertukar pikiran tentang regulasi baru tentang pendidikan, terutama yang berkenaan kurikulum dan penyusunan perangkat pembelajaran. "

Moh. Yasin, guru Al Quran - Hadis pada MTs. Negeri 38 mengungkapkan pengalamannya, "kepemimpinan pengawas madrasah patut diacungkan jempol, tiap permasalahan yang dihadapi guru PAI (baik yang menyangkut proses belajar mengajar atau etika) selalu dicarikan solusi yang tepat. Dalam memberikan informasi kedinasan tentang pengembangan keagamaan di madrasah cepat disampaikan. Dengan demikian para guru PAI MTs binaan cukup segan terhadap pengawas PAI tersebut."

Sedangkan Zakaria (bukan nama sebenarnya), guru Akidah Akhlak pada MTs. Swasta Al Wathoniyah 14 yang telah bertugas selama 12 tahun, menjelaskan "Pintu madrasah kami selalu terbuka kepada pengawas madrasah. Kami menyadari bahwa, pengawas madrasah adalah pembina dan pembimbing yang memberikan pencerahan demi kemajuan lembaga madrasah kami. Kehadiran pengawas madrasah selalu memberikan informasi terkini, pembimbingan yang kami butuhkan selalu dipenuhi, sehingga terkesan bahwa pengawas adalah orang tua kami."

Tidak jauh berbeda dengan Zakaria, Moh. Daud guru Fikih MTs. Swasta Al Wathoniyah 43, menganggap dirinya adalah mitra pengawas. Kami selalu menunggu kehadiran pengawas untuk melihat perkembangan kompetensi guru PAI dan lembaga madrasah kami. Ketika melakukan supervisi sikap pengawas madrasah tidak otoriter. Pengawas madrasah sangat demokratis dan bijak dalam melakukan pembinaan dan pembimbingan kepada kami."

Berdasarkan hasil wawancara dengan para guru PAI pada MTs. Negeri dan Swasta di atas dapat disimpulkan, maka persepsi guru-guru PAI MTs terhadap kepemimpinan pengawas madrasah adalah positif atau berkategori baik.

\section{Pembahasan}

Pada item nomor 1 tentang pernyataan persepsi guru PAl terhadap kepemimpinan pengawas, yaitu: "Pengawas bersikap demokratis dalam membina guru-guru" secara kuantitatif mendapat nilai 85,00 (kategori B). Bila dikomparasikan dengan hasil wawancara dengan semua guru PAl, terutama Abdullah (guru PAI MTs. Negeri 5), Hj. Maryam (guru PAI Negeri 5), Siti Qomariyah (guru PAI MTs Negeri 38) dan Zakaria (guru PAI Al Wathoniyah 14) yang mempersepsikan kepemimpinan pengawas yang demokratis dan tidak otoriter. Blake dan Mouton dalam (Newstroom \& Devis, 1999) mengindikasikan perilaku manajemen atas dasar berbagai cara yang membuat gaya kepemimpinan berorientasi kepada tugas dan karyawan. Pada gaya kepemimpinan 9.9. menjelaskan adalah demokratis, perhatian tinggi, baik terhadap tugas maupun orang. Gaya kepemimpinan pengawas madrasah yang dipersepsikan para guru PAI saat wawancara sebagai gaya demokratis terkait atau berhubungan dengan instrumen pernyataan nomor 1.

Pada item nomor 2 tentang pernyataan persepsi guru PAl terhadap kepemimpinan pengawas, yaitu: "Pengawas tidak memaksa guru PAI untuk mengerjakan tugas" mendapat nilai 77,5 (kategori B). Bila dikomparasikan dengan pendapat para guru PAI saat wawancara saling terkait atau berbuhungan, terutama pendapat Siti Qamariyah (guru PAI MTs. Negeri 5), Moh. Daud (guru PAI MTs. Al Wathoniyah 43) dan Zakaria (guru PAI MTs. Al Wathoniyah 14) mempersepsikan kepemimpinan pengawas madrasah tidak otoriter atau tidak memaksakan kehendak.

Pada item nomor 3 tentang pernyataan persepsi guru PAl terhadap kepemimpinan pengawas, yaitu: “Pengawas mengajak guru PAl untuk berpartisipasi dalam pembuatan keputusan" secara kuntitatif mendapat nilai 75 (kategori B). Bila dikomparasikan dengan pendapat para guru PAI saat wawancara saling terkait atau berbuhungan, terutama pendapat Abdullah dan $\mathrm{Hj}$. Maryam (keduanya, guru PAI MTs. Negeri 5), Siti Qamariyah (guru MTs Negeri 38) dan Zakaria (guru PAI MTs. Al Wathoniyah 14), mempersepsikan kepemimpinan pengawas madrasah yang bisa 
menerima pendapat orang lain, sehingga dengan begitu pengawas madrasah mengikutsertakan para PAI untuk berpartisipasi dalam membuat keputusan. Hal itu sejalan dengan pendapat Dale Timpe (Timpe, 1991) yang menjelaskan bahwa kepemimpinan adalah proses pengaruh sosial dimana manajer mencari keikutsertaan sukarela dari bawahan dalam usaha mencapai tujuan organisasi. Tak jauh berbeda dengan House et.al., dalam Gary Yukl (Yukl, 2007) bahwa "kepemimpinan adalah kemampuan individu untuk mempengaruhi, memotivasi, dan membuat orang lain mampu memberikan kontribusinya dengan efektivitas dan keberhasilan organisasi...".

Pada item pernyataan nomor 4 yaitu: "Pengawas menciptakan suasana kerja yang saling menghargai," secara kuantitatif mendapat nilai 79,166 (kategori B). Bila dikomparasikan dengan pendapat para guru, terutama $\mathrm{Hj}$. Maryam (guru PAI MTs Negeri 5); Siti Qamariyah dan Moh. Yasin (keduanya guru MTs Negeri 38); dan Zakaria (guru PAl Al Wathoniyah 14) yang mempersepsikan pengawas madrasah bisa bertukar pikiran dengan para guru PAl binaannya. Hal itu didukung oleh pendapat Gibb (dalam J. Saluju, 1996) bahwa ada 4 unsur utama dalam kepemimpinan (1) pemimpin yang menampilkan kepribadian pemimpinan; (2) kelompok; (3) pengikut yang muncul dengan berbagai kebutuhan, sikap, dan masalahmasalah, dan (4) situasi, yang meliputi keadaan pisik dan tugas kelompok. Ini mengindikasikan adanya saling keterkaitan antara hasil kuantitatif dengan kualitatif.

Pada item nomor 5 tentang pernyataan persepsi guru PAI terhadap kepemimpinan pengawas, yaitu: "Pengawas bekerja sama dengan para guru PAI dan kepala madrasah dalam proses pengambilan keputusan", secara kuantitatiif mendapat nilai 82,500 (kategori B). Bila dikomparasikan dengan pendapat semua para guru PAI saat wawancara saling terkait atau berbuhungan. Mendukung hal itu Garry Yukl (Yukl, 2007) menjelaskan kepemimpinan partisipatif menyangkut penggunaan berbagai macam prosedur keputusan yang memberi orang lain pengaruh tertentu terhadap keputusan pemimpin tersebut. Dengan kata lain kepemimpinan partisifatif mencakup konsultatif, pengambil keputusan bersama, pembagian kekuasaan, desentralisasi dan manajemen yang demokratis. mempersepsikan kepemimpinan pengawas madrasah tidak otoriter atau tidak memaksakan kehendak.

Pada item pernyataan nomor 6 yaitu: "Pengawas menghargai pendapat guru PAl" mendapat nilai 80,833 (kategori B). Bila dikomparasikan dengan pendapat semua para guru yang diwawancarai, bahwa pada dasarnya mereka mempersepsikan kepemimpinan pengawas madrasah dapat menghargai pendapat para guru PAI binaannya. Hal itu tak jauh berbeda dengan pendapat Gatto (Gatto, 1992), ada 4 gaya kepemimpinan yaitu: direktif, konsultatif, partisipatif dan delegasi. Pada gaya direktif umumnya pemimpin membuat keputusan-keputusan penting dan terlibat didalam pelaksanaannya. Gaya konsultatif dibangun atas gaya direktif, tetapi kurang otoriter. Pemimpin lebih banyak melakukan interaksi dengan organisasi. Hal itu sama dengan gaya kepemimpinan partisipatif oleh Gary Yukl, yang mencakup konsultatif, pengambil keputusan bersama, pembagian kekuasaan, desentralisasi dan manajemen yang demokratis.

Pada item nomor 7 tentang pernyataan guru PAl terhadap kepemimpinan pengawas madrasah, yaitu: "Pengawas memotivasi guru PAl agar berprestasi", secara kuantitatif mendapat nilai 79,166 (kategori B). Bila dikomparasikan dengan semua pendapat guru PAI (baik secara implisit atau eksplisit), bahwa kepemimpinan pengawas madrasah memberi dorongan untuk maju kepada para guru PAI. Bahkan pengawas madrasah menerima keluhan dan memberikan solusi atas permasalahan yang dihadapi para guru. Ini mengindikasikan pengawas madrasah memberikan motivasi agar guru PAI berprestasi.

Pada item pernyataan nomor 8 yaitu: "Pengawas bersikap demokratis saat melakukan supervisi akademik", mendapat nilai 80,833 (kategori B). Bila dikomparasikan dengan pendapat para guru PAI ketika diwawancarai, terutama $\mathrm{Hj}$. Maryam dan Abdullah (guru PAI MTs Negeri 5), Siti Qamariyah dan Moh. Yasin (guru PAI MTs Negeri 38); serta Zakaria (guru PAI MTs Al Wathoniyah 14 secara eksplisit 
menyatakan bahwa kepemimpinan pengawas saat melakukan tugas supervisi bersikap demokratis dan menguasai bidangnya. Hal itu didukung oleh pendapat Blake dan Mouton dalam (Newstroom \& Devis, 1999), “... Gaya 9.9. adalah demokratis, perhatian tinggi, baik terhadap tugas maupun orang. House et.al., dalam (Yukl, 2007) kepemimpinan individu mempengaruhi, memotivasi dan memberikan kontribusinya demi efektivitas dan keberhasilan oraganisasi...". Dengan demikian komparasi data antara kualitatif dan kuantitatif menunjukan kepemimpinan pengawas madrasah kategori baik.

Pada item pernyataan nomor 9 yaitu: "Pengawas memberi respon positif atas saran dan pendapat guru PAl", " mendapat nilai 80,833 (kategori B). Bila dikomparasikan dengan pendapat semua para guru yang diwawancarai, bahwa ternyata persepsi guru PAI terhadap kepemimpinan pengawas madrasah baik. Bahkan pengawas madrasah cukup responsif terhadap permasalahan yang dihadapi guru-guru PAI binaannya. Hal itu sejalan dengan (Gatto, 1992) yang melengkapi 4 gaya kepemimpinan yaitu: direktif, konsultatif, partisipatif dan delegasi. Juga (Newstroom \& Devis, 1999) menjelaskan kepemimpinan yang berorientasi pada tugas akan mengarahkan dan mengawasi anggotanya secara tertutup untuk menjamin tugas diselesaikan sesuai dengan yang diharapkan. Sedangkan pemimpin yang berorientasi pada anggotanya, mencoba untuk memberikan motivasi dibandingkan dengan mengawasi mereka.

Pada item pernyataan nomor 10 yaitu: “Pengawas memberi kesempatan kepada guru PAI untuk memilih pendekatan dan media pembelajaran PAI yang tepat", mendapat nilai 80,833 (kategori B). Bila dikomparasikan dengan pendapat para guru PAl ketika diwawancarai, ternyata berkaitan. Abdullah (guru PAI MTs Negeri 5) secara eksplisit mengutarakan pengawas memberi keleluasaan guru untuk menentukan model atau metode yang tepat sesuai materi dan pengawas pun selalu memberi bimbingan. Zakaria (guru PAl MTs Al Wathoniyah 43) dan Siti Qamariyah (guru MTs Negeri 38) keduanya mempersepsikan pengawas madrasah sebagai orang yang bijak, sangat demokratis, dan menguasai bidangnya.

Berdasarkan hasil data kuantitatif (dengan dukungan intrumen observasi) dan kualitatif (dengan dukungan wawancara) dari para guru PAI, maka dapat disimpulkan bahwa persepsi guru PAl terhadap kepemimpinan pengawas madrasah adalah positif atau berkategori baik.

\section{PENUTUP}

\section{Simpulan}

Data kuantitatif hasil penelitian ini diperoleh melalui angket dengan 10 (sepuluh) pernyataan tentang persepsi guru PAI terhadap kepemimpinan pengawas madrasah, dengan skor nilai rata-rata 79,916 (kategori baik).

Hasil wawancara dari 6 (enam) guru PAI (20\% dari responden) merupakan data kualitatif. Kedua data tersebut (data kuantitatif dan kualitatif) dikomparasikan, sehingga dapat disimpulkan, bahwa persepsi guru PAI terhadap kepemimpinan pengawas madrasah adalah berkategori baik.

\section{Rekomendasi}

Mengingat sikap kepemimpinan pengawas madrasah dapat mempengaruhi kinerja guru dan hubungan antar lembaga terkait, maka dikesempatan ini penulis merekomendasikan sebagai berikut.

a. Pengawas madrasah hendaknya saling bekerjasama dengan sesama pengawas madrasah dan kepala madrasah untuk memecahkan permasalahan yang berkaitan dengan perkembangan pendidikan terkini.

b. Pengawas madrasah hendaknya selalu berkoordinasi atau memberikan informasi kepada Kepala Kantor Kementerian Agama Kota/Kabupaten, agar selalu meng-up date informasi kedinasan.

c. Pengawas madrasah hendaknya sering melakukan dialog pada forum pengkajian permasalahan yang dihadapi di madrasah, baik yang bersipat kedinasan maupun non kedinasan atau keagamaan, dan sebagainya. 


\section{DAFTAR PUSTAKA}

Anwar, H. (2012). Korelasi antara Motivasi Berprestasi dan Penilaian Pengawas Terhadap Gaya Kepemimpinan Kepala Kementerian Agama Kota dengan Kinerja Pengawas Madrasah. $P$.

Arikunto, S. (2010). Prosedur Penelitian Suatu pendekatan Praktek. Jakarta: Rineka Cipta.

Cohen, W. A. (2002). The New Art of The Leader; Seni Baru Kepemimpinan. (H. Leko, Ed.) Jakarta: PT. Prenhallindo.

Creswell, J. W. (2014). Research Design: Qualitative Quantitative and Mixed Methods Approaches. Thousand Oaks: SAGE Publications, Inc.

Djatmiko, Y. H. (2005). Perilaku Organisasi. Bandung: Alfabeta.

Drever, J. (1988). Kamus Psikologi (The Penguin Dictionary of Psychology). (N. Simanjuntak, Ed.) Jakarta: PT. Bina Aksara.

Echols, J. M., \& Shadily, H. (1992). Kamus Inggris Indonesia. Jakarta: Gramedia.

Gatto, R. P. (1992). Teamwork Through Flexible Leadership. Pittsburgh: CTA. Press.

Ivancevich, J. M., Konopaske, R., \& Matteson, M. T. (2006). Perilaku dan Manajemen Organisasi (Organizational Behavior and Management, Seventh Edition). (G. Gania, Ed.) Jakarta: Erlangga.

Kreitner, R., \& Kinicki, A. (2003). Perilaku Organisasi (Organizational Behavior). (E. Suandy, Ed.) Jakarta: PT. Salemba Empat.

Luthan, F. (2006). Perilaku Organisasi (Organizational Behavior 10th Edition). (A. V. Yuono, S. Purwanti, T. Arie P, \& R. Winong, Eds.) Yogyakarta: Andi Copyright.

Moleong, L. J. (2007). Metodologi Penelitian Kualitatif. Bandung: Remaja Rosdakarya.

Newstroom, J., \& Devis, K. (1999). Organisation Behavior Human Behavior Work. New York: McGrawHill Companies, Inc.

Pasmore, W. A. (1994). Creating Strategic Change, Designing the Flexible High-Performing Organisation. New York: John Wiley \& Sons, Inc.

Peraturan Menteri Agama Nomor 2 Tahun 2012 tentang Pengawas Madrasah dan Pengawas Pendidikan Agama Islam pada Sekolah. (2012).

Peraturan Menteri Pendayagunaan Aparatur Negaradan Reformasi Birokrasi Nomor 21 Tahun 2010 Tentang Jabatan Fungsional Pengawas Sekolah dan Angka Kreditnya. (2010).

Robbins, S. P. (1996). Organisation Behavior. New Jersey: Englewood Cliffs.

Robbins, S. P., \& Judge, T. A. (2008). Perilaku Organisasi (Organizational Behavior, 12th ed). (D. Angelica, R. Cahyani, \& A. Rosyid, Eds.) Jakarta: PT. Salemba Empat.

Salusu, J. (1996). Pengambilan Keputusan Stratejik untuk Organisasi Publik dan Organisasi Nonprofit. Jakarta: Grasindo.

Sugiyono. (2012). Metode Penelitian Kuantitatif, Kualitatif dan R\&D (Vol. 15). Bandung: Alfabeta.

Terry, G. R. (1960). Principle of Management (Vol. 3). Homewood. Illionis: Record D. Irwin, Inc.

Timpe, A. D. (1991). Kepemimpinan (The Art and Sciece of Business Management Leadership). (S. Budidharmo, Ed.) Jakarta: PT. Elex Media Computindo.

Yukl, G. (1994). Leadership in Organisations. Prentice Hall International.

Yukl, G. (2007). Leadership in Organization: Kepemimpinan dalam Organisasi. (Supriyanto, Ed.) Jakarta: PT. Indeks. 